\title{
Dampak Pemberian Seng dan Probiotik terhadap Lama Diare Akut di Rumah Sakit Prof. DR. RD. Kandou Manado
}

\author{
Christie Manoppo \\ Bagian Ilmu Kesehatan Anak, Fakultas Kedokteran Universitas Sam Ratulangi, Manado
}

\begin{abstract}
Latar belakang. Pemberian suplementasi seng dan probiotik selama diare akut pada anak telah menunjukkan dampak positif terhadap lama diare. Seng memiliki fungsi dalam memperpendek lama diare dan penggunaan probiotik bermanfaat dalam mencegah dan mengobati diare akut.

Tujuan. Mengevaluasi efektivitas dari seng dan/atau probiotik dalam penanganan diare akut pada anakanak.

Metode. Penelitian deskriptif dengan menggunakan data retrospektif antara bulan Januari 2007-Desember 2008 di Bangsal Gastroenterologi Anak Rumah Sakit Prof. Dr. RD Kandou Manado. Terdapat 201 anak dengan diare akut yang dibagi dalam 4 kelompok. Kelompok I yang mendapat pengobatan dengan seng, kelompok II mendapat seng dan probiotik hidup, kelompok III mendapat seng dan probiotik mati dan kelompok IV hanya mendapat probiotik mati. Variabel pengamatan adalah lama diare.

Hasil. Subjek penelitian 201 anak, 123 anak laki-laki $(61,2 \%)$ dan 78 anak perempuan $(38,8 \%)$, usia (ratarata dan SD) menurut kelompok ( $\mathrm{p}=0,57)$ dibagi atas 44,6\% usia kurang dari 1 tahun, 46,6\% umur 1-3 tahun, 4,8\% umur 3-5 tahun, 3,8\% berusia di atas 5 tahun. Lama diare pada kelompok I adalah 4,85 hari ( $95 \%$ CI : $4.44 ; 5.26$ ), kelompok II 4,16 hari ( 95\% CI : $2.66 ; 5.65$ ), kelompok III 5,77 hari ( $95 \%$ CI : $4.51 ; 7.03$ ) dan kelompok IV 5,86 hari ( $95 \%$ CI : $4.87 ; 5.44$ ).

Kesimpulan. Lamanya diare pada keempat kelompok diatas menunjukkan perbedaan yang tidak bermakna ( $>>0,05)$. Hasil uji F lama diare ke-4 kelompok diperoleh p=0,08. (Sari Pediatri 2010;12(1):17-20).
\end{abstract}

Kata kunci: lama diare, seng, probiotik

$\mathrm{P}$ enyakit diare merupakan satu dari penyebab utama kesakitan dan kematian pada anak di bawah usia lima tahun di negara berkembang. ${ }^{1}$ Lama diare akut rata-rata berlangsung sekitar

Alamat korespondensi:

Dr. Christie Manoppo, SpA. Bagian Ilmu Kesehatan Anak FK UNSRAT/ RSU Prof. Dr. R.D. Kandou Manado. Telepon: (0431) 821652; Fax.: (0431) 859091. lima hari namun pada beberapa kasus, diare dapat berlangsung lebih dari 14 hari. $^{2}$ Pada beberapa tahun terakhir, penanganan diare akut pada anak dengan memberikan rehidrasi oral pada stadium awal sakit. ${ }^{3}$ Pada penelitian meta-analisis sebelumnya telah menunjukkan efek terapeutik dari probiotik, terutama Lactobacillus $G G$, pada diare akut yang disebabkan oleh rotavirus. ${ }^{4,5}$ Tujuan pengobatan untuk mengurangi lama diare selama beberapa jam. ${ }^{4,5}$ Selain probiotik, beberapa penelitian 
lain telah menunjukkan bahwa dengan menambahkan suplementasi seng oral dapat juga mengurangi lama diare dan tingkat keparahan penyakit diare akut pada anak. ${ }^{3}$ Suplementasi seng yang diberikan selama diare dapat mengurangi lama dan tingkat keparahan dari episode diare dan jika diberikan selama 14 hari mulai dari saat berlangsungnya dan setelah diare, dapat mengurangi insidens diare dalam waktu 2-3 bulan. ${ }^{1}$ Meskipun seng dan probiotik bekerja melalui mekanisme yang berbeda, namun dapat memberikan efek sinergis apabila keduanya dikombinasikan. Pada suatu penelitian, rhesus monkeys, menunjukkan dampak pencegahan dengan mengkombinasikan probiotik dan seng. ${ }^{6}$ Walaupun demikian, kombinasi dari probiotik dan seng dalam pengobatan diare pada anak belum pernah diteliti. ${ }^{3}$ Tujuan dari penelitian untuk mengevaluasi efektivitas seng dan/ atau probiotik dalam pengobatan diare akut pada anak.

\section{Metode}

Melalui penelitian retrospektif, didapatkan 201 anak yang di rawat-inap di Bangsal Gastroenterologi RS Prof. RD Kandou mulai Januari 2007 sampai Desember 2008. Kriteria inklusi yang digunakan adalah anak berusia 1 bulan sampai kurang dari 10 tahun, dengan diare akut dari tanpa dehidrasi sampai dehidrasi ringan sedang. Diare akut didefinisikan sebagai diare yang terjadi secara mendadak pada anak yang sebelumnya sehat berupa keluarnya tinja cair lebih dari atau sama dengan empat kali yang berlangsung lebih dari satu hari dan kurang dari tujuh hari. Kriteria eksklusi mencakup diare dengan dehidrasi berat, ASI eksklusif, disentri klinis, toksisitas, obesitas dan anak dengan imunosupresif.

Data yang dicatat adalah umur, jenis kelamin, berat badan, tinggi badan, derajat dehidrasi, lama diare dihitung berdasarkan hari, sejak masuk rumah sakit sampai diperbolehkan rawat jalan. Hal ini yang dinilai adalah frekuensi buang air besar dan perubahan konsistensi feses (dalam penelitian ini yang dicatat hanyalah lama diare, bukan lama perawatan di rumah sakit). Penelitian deskiptif yang menggunakan data retrospektif, bertujuan untuk menilai dampak pemberian seng dan probiotik baik secara bersamaan maupun secara tunggal. Pasien yang diteliti dibagi menjadi 4 kelompok. Kelompok I mendapatkan seng, kelompok II mendapat seng dan probiotik hidup, kelompok III mendapat seng dan probiotik mati, dan kelompok IV mendapat probiotik mati. Variabel pengamatan utama adalah lama diare. Analisis statistik menggunakan program SPSS versi 17. Perbedaan antar kelompok digunakan one way anova dengan uji F. Nilai $\mathrm{P}<0,05$ dinyatakan bermakna.

\section{Hasil}

Pada periode Januari 2007-Desember2008 terdapat 123 anak laki-laki $(61,2 \%)$ dan 78 anak perempuan $(38,8 \%)$ yang memenuhi kriteria inklusi. Dari data yang dikumpulkan dan dicatat, termasuk juga status nutrisi anak dengan gizi kurang 124 anak $(61,7 \%)$, gizi baik 65 anak (32,3\%), dan overweight 12 anak (6,0\%). Data diare akut berdasarkan derajat dehidrasi, yaitu dehidrasi ringan-sedang 100 anak (49,8\%) dan tanpa dehidrasi 101 anak (50,2\%) berdasarkan kelompok.

Lama diare (dihitung dengan memakai satuan hari) ke-empat kelompok ini menunjukkan tidak ada perbedaan yang bermakna antar kelompok yang menggunakan seng, probiotik hidup maupun mati atau kombinasi keduanya $(\mathrm{p}=0,080)$. Telah dilakukan

Tabel 1. Jumlah sampel dari masing-masing kelompok

\begin{tabular}{clcc}
\hline Kelompok & Karakteristik & jumlah & $\%$ \\
\hline I & Seng & 132 & 65,7 \\
II & Seng+probiotik hidup & 13 & 6,5 \\
III & Sengk+probiotik mati & 35 & 17,4 \\
IV & Probiotik mati & 21 & 10,4 \\
& Total & 201 & 100,0 \\
\hline
\end{tabular}

Tabel 2. Lama diare berdasarkan kelompok

\begin{tabular}{lccccc}
\hline Kelompok & $\begin{array}{c}\text { Rata - rata } \\
\text { (hari) }\end{array}$ & $\begin{array}{c}\text { SB } \\
\text { (hari) }\end{array}$ & IK 95\% & F & P \\
\hline I (Seng) & 4,85 & 2,38 & 4,$44 ; 5,26$ & & \\
II (Seng+probiotik hidup) & 4,15 & 2,48 & 2,$66 ; 5,65$ & \multirow{2}{*}{2,287} & 0,08 \\
III (Seng+probiotik mati) & 5,77 & 3,67 & 4,$51 ; 7,03$ & 2,$287 ; 6,85$ & \\
IV (Probiotik mati) & 5,86 & 2,18 & 4,87 & \\
\hline
\end{tabular}


pada penghitungan perbedaan antar status gizi dan derajat dehidrasi terhadap lama diare. Kedua variabel tersebut juga menunjukkan tidak ada perbedaan yang bermakna baik status gizi maupun derajat dehidrasi terhadap lama diare $(\mathrm{p}>0,05)$.

\section{Diskusi}

Secara umum, diare diartikan sebagai peningkatan frekuensi atau penurunan buang air besar secara konsisten. Di negara berkembang, rata-rata jumlah buang air besar (BAB) adalah tiga kali per hari. Diare diasosiasikan dengan meningkatnya jumlah feses, terutama konsistensi cair, yang lebih dari biasanya. $^{7}$ Suplementasi Lactobacillus selama diare akut telah didemonstrasikan memiliki dampak yang menguntungkan baik pada durasi diare maupun tingkat keparahan sakit. ${ }^{4-5}$ Pada penelitian lain, pasien anak rawat inap (6-60 bulan), yang diberi susu formula yang mengandung Bifidobacterium infantis dan Lactobacillus acidophilus dapat mengurangi lama diare selama 0,5 hari. Shamir dkk, ${ }^{3}$ juga mengatakan, pada pelayanan kesehatan tingkat pertama, bahwa dengan menambahkan $6 \times 10^{9}$ colony forming units Streptococcus thermophilus, Bifidobacterium lactis, Lactobacillus acidophilus ( $2 \times 10^{9}$ dari setiap strain) dan seng sebesar $10 \mathrm{mg} /$ hari secara signifikan menurunkan durasi diare akut pada anak usia 6-12 bulan (sekitar 15 jam) dan menginduksi dengan cepat kembali ke konsistensi normal. Pada diare akut, suplementasi seng mengurangi lama dan tingkat keparahan penyakit. Selanjutnya, suplementasi seng bila digunakan selama 4 bulan dapat menurunkan insidens prolonged diare pada anak. Sebaliknya, penambahan probiotik pada formula bayi dalam rhesus monkeys dapat menurunkan tingkat keparahan diare (diare yang sengaja diinduksi), tetapi tidak memiliki dampak yang menguntungkan dengan menambahkan seng. Pada penelitian di Peru melaporkan bahwa tingkat kesakitan lebih tinggi dengan suplementasi seng yang ditambahkan multivitamin dan mineral dibandingkan hanya suplementasi seng. ${ }^{8}$

Weizman $\mathrm{dkk},{ }^{9}$ menunjukkan bahwa perbedaan durasi demam dan diare adalah lebih dari satu hari, hal ini memegang peran penting dalam menentukan terapi. Dengan adanya penelitian berskala besar dan jangka panjang diharapkan bentuk terapi yang lebih (misalnya durasi dan dosis) baik untuk evaluasi secara klinik.
Sebagian besar tinja patogen adalah virus. Analisis feses untuk rotavirus sekitar 34\%-41\%, dan lainnya sekitar 51\%-57\% biakan bakteri adalah negatif. Trivedia dkk ${ }^{1}$ menunjukkan bahwa frekuensi luaran tinja menurun secara signifikan pada total pasien yang menggunakan suplementasi seng $(\mathrm{p}<0.05)$ pada hari ketiga dan kelima sebagai pembanding dengan kelompok kontrol plasebo. Hasil penelitian tersebut menunjukkan penurunan frekuensi diare secara signifikan (36\%) dan luaran tinja (45\%) karena suplementasi seng pada hari ketiga. Kesimpulan dari penelitian kami diindikasikan bahwa suplementasi seng pada diare akut secara efektif mengurangi baik frekuensi diare maupun keluaran tinja. Rahman $\mathrm{dkk}^{10}$ melaporkan dalam penelitian mereka, suplementasi seng dan tembaga (copper) pada anak di Bangladesh, bahwa mereka yang mendapat suplementasi seng selama dan setelah diare, durasi diare menjadi $24 \%$ lebih pendek, $15 \%$ insidens diare lebih rendah, dan cenderung lebih sedikit pasien yang harus dirawat inap karena diare. Sebaliknya, pada penelitian Patel $\mathrm{dkk}^{11}$ melaporkan bahwa lamanya diare pada anak ditentukan oleh keterlibatan tingkat keparahan penyakit bukan pada suplementasi. Namun penelitian ini tidak menunjukkan tingkat keparahan penyakit. Sebuah studi meta-analisis dari lima studi tentang suplementasi seng pada pengobatan diare akut ditemukan bahwa perkiraan berkurangnya durasi diare $16 \%$. Mekanisme efektivitas seng sebagai terapi dalam mengurangi durasi diare termasuk memperbaiki absorpsi air dan elektrolit dari usus, regeneralisasi cepat epitel usus, meningkatkan respon imun, mempercepat klirens kuman diare yang patogen dari usus. ${ }^{12}$ Pada penelitian, kami tidak memperlihatkan perbedaan tingkat kesakitan di antara kelompok. Dampak yang menguntungkan penggunaan suplementasi seng tidak didapatkan, namun kami juga tidak menemukan peningkatan angka kesakitan pada anak diare yang mendapat terapi suplementasi seng. Penelitian kami merupakan penelitian retrospektif yang mempunyai beberapa keterbatasan. Besar sampel kecil, karena hanya terbatas pada pasien yang rawat-inap selama dua tahun, tanpa melihat jumlah, dan frekuensi tinja. Hasil temuan dari penelitian kami menunjukkan bahwa suplementasi seng dan probiotik hidup pada diare akut secara efektif mengurangi lama diare dibandingkan dengan kelompok lainnya meskipun tidak berbeda bermakna, Sebagai kesimpulan, meskipun suplementasi kombinasi dari Streptococcus thermophilus, Bifidobacterium lactis, Lactobacillus 
acidophilus, dan seng dapat memperpendek tingkat keparahan sakit dan lama diare pada anak usia 6 bulan-sampai 5 tahun, namun dampak kombinasi seng dan probiotik dibandingkan dengan hanya seng atau probiotik saja tidak berbeda.

\section{Daftar Pustaka}

1. Trivedia SS, Chudasamab RK, Patela N. Effect of zinc supplementation in children with acute diarrhea: randomized double blind controlled trial. Gastroenterolgy research 2009;2:168-74.

2. Valois SV, Costa-Ribeiro Jr H, Mattos Â, Ribeiro TC, Mendes CM, Lifshitz F. Controlled, double-blind, randomized clinical trial to evaluate the impact of fruit juice consumption on the evolution of infants with acute diarrhea. Nutritional journal 2005; 4:23.

3. Shamir R, Makhoul IR, Etzioni A, Shehadeh N. Evaluation of a diet containing probiotics and zinc for the treatment of mild diarrheal illness in children younger than one year of age. Journal of the American college of nutrition. 2005;24:370-75.

4. Van Niel C, Feudtner C, Garrison MM, Christakis DA. Lactobacillus therapy for acute infectious diarrhea in children: A meta analysis. Pediatrics 2002;109 :678-84.

5. Szajewska H, Mrukowicz J. Probiotics in the treatment and prevention of acute infectious diarrhea in infants and children: A systematic review of published randomized, double-blind, placebo controlled trials. J Pediatr
Gastroenterol Nutr 2001;33:17-25.

6. Kelleher SL, Casas I, Carbajal N, Lo“nnerdal B. Supplementation of infant formula with the probiotic lactobacillus reuteri and zinc: impact on enteric infection and nutrition in infant rhesus monkeys. Journal of pediatric gastroenterology and nutrition 2002;35:162-8.

7. Lukacik M, Thomas RL, Aranda JV. A meta-analysis of the effects of oral zinc in the treatment of acute and persistent diarrhea. Pediatrics 2008;121:326-36.

8. Penny ME, Marin RM, Duran A, Peerson JM, Lanata CF, Lonnerdal B, Black RE, Brown KH. Randomized controlled trial of the effect of daily supplementation with zinc or multiple micronutrients on the morbidity, growth, and micronutrient status of young Peruvian children. Am J Clin Nutr 2004; 79:457-65.

9. Weizman Z, Asli G, Alsheikh A. Effect of a probiotic infant formula on infections in child care centers: comparison of two probiotic agents. Pediatrics 2005;115:5-9.

10. Rahman MM, Tofail F, Wahed MA, Fuchs GJ, Baqui $\mathrm{AH}$, Alvarez JO. Short-term supplementation with zinc and vitamin A has no significant effect on the growth of undernourished Bangladeshi children. Am J Clin Nutr 2002;75:87-91.

11. Patel AB, Dhande LA, Rawat MS. Therapeutic evaluation of zinc and copper supplementation in acute diarrhea in children: double blind randomized trial. Indian Pediatr 2005;42:433-42.

12. Strand TA, Chandyo RK, Bahl R. Effectiveness and efficacy of zinc for the treatment of acute diarrhea in young children. Pediatrics 2002;5:109. 